\title{
Isolasi Bakteri Indigineous dari Limbah Cair Tahu dalam Mendegradasi Protein dan Melarutkan Fosfat
}

\section{Isolation of Indigineous Bacteria from Tofu Wastewater for Degrading Proteins and Solubilizing Phosphate}

\author{
MUHAMMAD ASRIL"' INDAH OKTAVIANI, SOVIA SANTI LEKSIKOWATI \\ Program Studi Biologi, Institut Teknologi Sumatera \\ Jalan Terusan Ryacudu, Way Huwi, Jati Agung, Lampung Selatan, Lampung 35365. \\ Email: m.asril@bi.itera.ac.id
}

\begin{abstract}
The tofu industry in Indonesia is growing rapidly along with the consumption needs. This amount affects the production of the tofu wastewater that will be discharged into the environment. The waste contains high levels of $B O D, C O D$, and high protein organic substances. The discharged of the tofu wastewater without going through a good process of separation and treatment caused odor and pollution in the water and the soil environment. This study aims to examine the amount of production, a chemical characteristic, and bacterial potential (the genus of Pseudomonas and Aeromonas, proteolytic bacterial isolates, and potential phosphate solvent bacteria) which can be used as a reference for bioconversion of higher tofu wastewater. The method used in this study was water sampling, chemical characteristic testing $(B O D$, $C O D$, total protein, and $\mathrm{pH}$ ), the bacterial isolation of Pseudomonas and Aeromonas using GSP media, isolation of proteolytic bacteria using nutrient agar + Skim milk media and testing the solubilizing phosphate ability in pikovskaya media. The results showed the production of the tofu liquid waste reached 4000 liters/day with BOD, COD, total protein and $\mathrm{pH}$ content is $3210 \mathrm{mg} / \mathrm{L}, 7102 \mathrm{mg} / \mathrm{L}, 20.74 \%$ and 5 , respectively. The amount of indigenous bacteria in wastewater from Pseudomonas were $72 \times 102 \mathrm{cfu} / \mathrm{ml}$ ), Aeromonas were $\left.18 \times 10^{2} \mathrm{cfu} / \mathrm{ml}\right)$, and total proteolytic bacteria were $\left.23.7 \times 10^{5} \mathrm{cfu} / \mathrm{ml}\right)$. Proteolytic bacteria obtained in this research were 28 isolates with diverse proteolytic abilities. In addition, 17 of the 28 proteolytic bacteria isolates have the ability to soluble phosphate on pikovskaya medium. These results show that the production of the tofu liquid waste is quite high. Therefore, the chemical character and the presence of bacteria in it have the potential to be developed and can be used as a reference for bioconversion of waste before being discharged into the environment.
\end{abstract}

Keywords: Aeromonas, proteolytic bacteria, tofu wastewater, phosphate solubilizing bacteria, Pseudomonas

\begin{abstract}
ABSTRAK
Industri tahu di Indonesia berkembang sangat pesat seiring dengan kebutuhan konsumsi masyarakat Indonesia. Jumlah ini berpengaruh terhadap produksi limbah cair tahu yang akan dibuang ke lingkungan. Limbah tersebut memiliki kandungan BOD, COD dan bahan organik berupa protein yang cukup tinggi. Limbah cair tahu jika dibuang lingkungan tanpa melalui proses pemisahan dan perlakuan yang baik dapat menimbulkan bau dan pencemaran di lingkungan air dan tanah. Penelitian ini bertujuan untuk mengkaji jumlah produksi, karakteristik kimia dan potensi biologi (bakteri genus Pseudomonas dan Aeromonas, isolat bakteri proteolitik dan bakteri pelarut fosfat potensial) yang nantinya dapat digunakan sebagai acuan biokonversi limbah cair tahu yang semakin tinggi. Metode yang digunakan pada penelitian ini adalah pengambilan sampel, pengujian karakteristik kimia (BOD, COD, total protein dan $\mathrm{pH}$ ), isolasi bakteri genus Pseudomonas dan Aeromonas pada media GSP, isolasi bakteri proteolitik di media Nutrien agar + Skim milk dan pengujian kemampuan melarutkan fosfat pada media pikovskaya. Hasil menunjukkan bahwa limbah cair yang diproduksi setiap harinya mencapai 4000 liter/hari dengan kandungan BOD, COD, total protein dan $\mathrm{pH}$ berturut-turut sebesar $3210 \mathrm{mg} / \mathrm{L}, 7102 \mathrm{mg} / \mathrm{L}, 20.74 \%$ dan 5. Jumlah bakteri indigeous dalam limbah cair tahu dari genus Pseudomonas adalah $72 \times 10^{2} \mathrm{cfu} / \mathrm{ml}$, genus Aeromonas adalah $18 \times 10^{2} \mathrm{cfu} / \mathrm{ml}$ dan total bakteri proteolitik adalah $23.7 \times 10^{5} \mathrm{cfu} / \mathrm{ml}$. Bakteri proteolitik yang diperoleh berjumlah 28 isolat dengan kemampuan proteolitik yang cukup beragam. Selain itu, 17 dari 28 isolat bakteri proteolitik tersebut memiliki kemampuan melarutkan fosfat pada media pikovskaya. Hasil ini menunjukkan bahwa produksi limbah cair tahu yang cukup tinggi, karakteristik kimia serta keberadaan bakteri didalamnya memiliki potensi untuk dikembangkan dan dapat dijadikan sebagai acuan untuk biokonversi limbah sebelum dibuang ke lingkungan.
\end{abstract}

Kata kunci: Aeromonas, bakteri proteolitik, limbah cair tahu, bakteri pelarut fosfat, Pseudomonas 


\section{PENDAHULUAN}

\subsection{Latar Belakang}

Industri tahu di Indonesia berkembang sangat pesat seiring dengan kebutuhan konsumsi perkapita masyarakat Indonesia yang semakin meningkat. Indonesia memiliki 84.000 pabrik tahu dari skala rumah tangga hingga skala besar dengan pekerja lebih dari 100 pekerja ${ }^{(1)}$. Dalam produksi tahu membutuhkan 2,56 juta ton kedelai setiap tahunnya, dengan jumlah sebesar itu industri tahu mampu menghasilkan 20 juta $\mathrm{m}^{3}$ /tahun limbah cair dan 1.024 juta ton limbah padat ${ }^{(2)}$. Permasalahan utama dari limbah tahu di lingkungan adalah limbah yang dihasilkan selama proses pencucian, pengeringan dan pencetakan sangat tinggi. Limbah cair tahu mengandung kadar bahan organik yang sangat tinggi dan $\mathrm{pH}$ yang asam ${ }^{(3)}$, sehingga sulit untuk didegradasi di lingkungan. dan mengurangi kualitas air dan tanah karena mengandung bahan organik yang terlalu tinggi dan menyebabkan bau ${ }^{(4)}$.

Komponen bahan organik dalam limbah cair tahu yang sulit diserap oleh lingkungan dapat diproses dengan perlakuan kimia tetapi membutuhkan biaya yang mahal dan menimbulkan efek baru di lingkungan. Salah satu upaya yang sedang menjadi perhatian saat ini adalah dengan biokonversi limbah. Kebijakan menggunakan produk daur ulang hasil biokonversi sangat efisien dalam mengurangi jumlah polutan dan meningkatkan nilai ekonomi ${ }^{(5)}$. Salah satu upaya mengkonversi limbah cair tahu tersebut dengan menggunakan mikroba proteolitik indigenous dan bakteri pelarut fosfat yang diisolasi dari limbah tahu. Usaha ini perlu dilakukan pengkajian awal mengenai keberadaan bakteri proteolitik, pelarut fosfat dan bakteri lainnya seperti kelompok bakteri Pseudomonas yang memang sudah dikenal sebagai agen bioremediasi limbah.

\subsection{Tujuan Penelitian}

Penelitian ini bertujuan untuk mengkaji jumlah produksi, karakteristik kimia dan potensi biologi (bakteri genus Pseudomonas dan Aeromonas, isolat bakteri proteolitik dan bakteri pelarut fosfat potesial) yang nantinya dapat digunakan sebagai acuan biokonversi limbah cair tahu yang semakin tinggi.

\section{BAHAN DAN METODE}

\subsection{Bahan}

Sampel limbah cair tahu diperoleh dari Pabrik Tahu di daerah Kedamaian, Bandar Lampung. Sampel disimpan didalam botol gelap yang terlindungi dari sinar matahari.

\subsection{Metode}

Penelitian ini dilakukan pada bulan Mei 2018, dengan mengambil sampel limbah cair tahu pada pagi hari. Sampel diambil dari Pabrik tahu lalu dibawa ke Laboratorium untuk dilakukan tahapan penelitian selanjutnya.

Penelitian ini juga melakukan pengambilan data dengan wawancara kepada pekerja dan pemilik Pabrik tahu tersebut terkait jumlah produksi tahu dan limbah cair tahu. Selanjutnya dilakukan pengujian BOD, COD, kandungan protein dan $\mathrm{pH}$. Selanjutnya dilakukan isolasi bakteri proteolitik menggunakan media Nutrient Agar + Skim Milk 1\% dengan metode spread plate dan diinkubasi pada suhu $37 \mathrm{C}$ selama 24 jam. Uji positif ditandai dengan adanya zona bening yang terbentuk di sekeliling koloni akibat adanya hidrolisis kasein menjadi nitrogen terlarut. Koloni tunggal yang menghasilkan zona bening kemudian dimurnikan. Isolat bakteri proteolitik yang telah murni, ditumbuhkan kembali pada medium NA + Skim Milk 1\% untuk indeks proteolitik (IP) pada masing-masing koloni untuk mengetahui daya degradasi bakteri terhadap protein didalam media dengan persamaan berikut ${ }^{(6)}$ : $I P=\frac{\text { Diameter Zona Bening }(\mathrm{mm})-\text { Diameter Koloni }(\mathrm{mm})}{\text { Diameter Koloni }(\mathrm{mm})}$

Keterangan

IP : Indeks Proteolitik

Selain mengisolasi bakteri proteolitik juga dilakukan isolasi bakteri genus Pseudomonas dan Aeromonas pada media GSP (Glutamate Starch Phenol) agar yang terdiri dari $10 \mathrm{~g}$ Sodium L-glutamate, $20 \mathrm{~g}$ Starch, $2 \mathrm{~g}$ Potassium dihydrogen phosphate, $0.5 \mathrm{~g}$ Magnesium sulfate, 0.36 Fenol red dan $12 \mathrm{~g}$ Agar dilarutkan dalam 1 liter akuades dengan pH 7.2. Media ini merupakan media spesifik untuk kelompok bakteri Pseudomonas dan Aeromonas. Koloni bakteri yang tumbuh berwarna kuning digolongkan dalam kelompok Aeromonas, sedangkan koloni warna merah digolongkan dalam kelompok Pseudomonas.

Setelah didapatkan isolat yang posititf menghasilkan protease, dilakukan pengujian kemampuan melarutkan fosfat pada media Pikovskaya yang yang terdiri atas $10 \mathrm{~g} \mathrm{C}_{6} \mathrm{H}_{12} \mathrm{O}_{6}$,

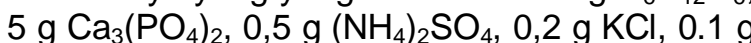
$\mathrm{MgSO}_{4} \cdot 7 \mathrm{H}_{2} \mathrm{O}, 0,002 \mathrm{~g} \mathrm{MnSO}{ }_{4} \cdot 7 \mathrm{H}_{2} \mathrm{O}, 0,002 \mathrm{~g}$ $\mathrm{FeSO}_{4} .7 \mathrm{H}_{2} \mathrm{O}, 0,1 \mathrm{~g} \mathrm{NaCl}, 0,5 \mathrm{~g}$ ekstrak khamir, $20 \mathrm{~g}$ agar-agar dalam $1000 \mathrm{ml}$ dengan $\mathrm{pH} 7$ dengan cara dititik pada media dan diinkubasi selama 7 hari pada suhu ruang. Setelah inkubasi, diamati zona bening yang terbentuk di sekitar koloni. Zona bening disekitar koloni menunjukkan bahwa isolat bakteri mampu melarutkan P pada media pikovskaya. 


\section{HASIL DAN PEMBAHASAN}

\subsection{Jumlah Produksi Limbah Cair Tahu}

Pabrik tahu di Jalan Kedamaian, Bandar Lampung mampu memproduksi tahu berkisar antara 500-1.000 kg setiap harinya. Jumlah produksi yang tinggi tersebut menghasilkan limbah cair tahu yang cukup banyak. Total limbah cair tahu yang dihasilkan setiap harinya mencapai 4000 liter (Tabel 1). Jumlah limbah cair tahu yang sangat tinggi tersebut memiliki potensi mencemari lingkungan akan tetapi juga memiliki potensi sebagai sumber mikroba potensial. Mikroba indigenous asal limbah cair tahu jika dikelola dengan baik dapat dijadikan sebagai alternatif biokonversi limbah menjadi sesuatu yang berguna. Pemanfaatan limbah cair industri tahu sudah banyak dilakukan diantaranya sebagai pupuk cair organik untuk pertumbuhan dan produksi tanaman kangkung darat $^{(7)}$. Selain itu, limbah cair tahu dapat dijadikan sebagai sumber bioenergi seperti produksi biogas ${ }^{(8)}$.

Tabel 1. Produksi Tahu dan Limbah Cair Tahu per hari

\begin{tabular}{ll}
\hline \multicolumn{1}{c}{ Parameter } & \multicolumn{1}{c}{ Jumlah } \\
\hline Kapasitas produksi tahu & $500-1.000 \mathrm{~kg}$ \\
Produksi total limbah & $800 \mathrm{Liter} / 100 \mathrm{~kg}$ \\
$\begin{array}{l}\text { Rata-rata produksi limbah } \\
\text { cair tahu }\end{array}$ & $4000 \mathrm{liter} / \mathrm{hari}$ \\
\hline
\end{tabular}

\subsection{Karakteristik Kimia Limbah Cair Tahu}

Karakteristik kimia sangat penting dalam mengkaji terkait limbah yang dibuang ke lingkungan. Karakteristik kimia meliputi BOD, $\mathrm{COD}$, Kadar protein dan $\mathrm{pH}$ memiliki korelasi terhadap standar baku apakah limbah tersebut layak dibuang ke lingkungan. Hasil pengujian menunjukkan bahwa limbah cair tahu yang dihasilkan sangat tidak memenuhi standar baku untuk dibuang langsung ke lingkungan (Tabel 2). Pada umumnya air lingkungan yang telah tercemar memiliki kandungan oksigen yang sangat rendah. Hal ini disebabkan oleh jumlah oksigen yang terlarut di dalam air diserap oleh mikroorganisme untuk mendegradasi bahan organik yang terbuang sehingga menjadi bahan yang mudah menguap. Makin sedikit kandungan oksigen terlarut didalam air maka makin tinggi jumlah buangan bahan organiknya. Kandungan konsentrasi kebutuhan oksigen biologi atau BOD di dalam air merupakan salah satu indikator tingginya kandungan bahan organik ${ }^{(9)}$.
Tabel 2. Karakteristik Kimia Cair Tahu

\begin{tabular}{lcc}
\hline \multicolumn{1}{c}{ Parameter } & Nilai & Baku Mutu \\
\hline BOD $(\mathrm{mg} / \mathrm{l})$ & 3210 & 150 \\
COD $(\mathrm{mg} / \mathrm{l})$ & 7102 & 300 \\
Total protein $(\%)$ & 20,74 & - \\
$\mathrm{pH}$ & 5 & $6-9$ \\
\hline
\end{tabular}

Kandungan protein pada pengujian menunjukkan bahwa kadar bahan organik cukup tinggi sehingga berpengaruh terhadap kadar BOD didalam limbah. Tingginya kadar BOD dan COD disebabkan oleh beberapa hal di antaranya tingginya bahan organik yang berasal dari limbah yang dihasilkan ${ }^{(10)}$. Kandungan limbah tersebut jika dibuang ke lingkungan tanpa melalui proses secara biologi maupun kimia dapat menyebabkan bau dan polusi di lingkungan air dan $\operatorname{tanah}^{(3)}$. Selain itu, kandungan COD dengan rentang 5000-8500 mg/L mengindikasikan bahwa limbah cair tahu tersebut sangat berpotensi untuk dijadikan sumber produksi bioenergi ${ }^{(8)}$.

\subsection{Jumlah Total Bakteri Genus Pseudomonas dan Genus Aeromonas}

Hasil isolasi bakteri Pseudomonas dan Aeromonas dari limbah cair tahu pada media GSP diperoleh bahwa jumlah genus Pseudomonas lebih tinggi dari genus Aeromonas (Tabel 3). Populasi Pseudomonas dalam suatu limbah cukup menguntungkan. Beberapa laporan terkait dengan penggunaan Pseudomonas sebagai agen bioremediasi limbah. Pseudomonas mampu menghasilkan biosurfaktan yang mampu mendegradasi limbah. Salah satu Pseudomonas yang mampu menghasilkan biosurfaktan adalah $P$. fluorescens. Biosurfaktan yang dihasilkan oleh bakteri ini diproduksi pada media limbah cair tahu dan mampu mengemulsi minyak ${ }^{(11)}$. Selain itu, $P$. fluorescens mampu menekan populasi patogen dengan cara melindungi akar dari patogen dengan mengkolonisasi akar ${ }^{(12)}$. Sedangkan genus Aeromonas memiliki jumlah lebih sedikit dibandingkan dengan Pseudomonas. Keberadaan Aeromonas di lingkungan juga sebagai agen pengendali hayati. Salah satu contohnya adalah Aeromonas hydrophila. A. hydrophila mampu menghambat pertumbuhan Fusarium sp. secara in vitro ${ }^{(13)}$. Keberadaan kedua jenis bakteri ini didalam limbah cair tahu sangat potensial sebagai agen bioremediasi limbah dan dapat dijadikan sebagai agen biokonversi limbah untuk dijadikan sebagai biofertilizer. 
Tabel 3. Jumlah total bakteri genus Pseudomonas dan genus Aeromonas pada media GSP

\begin{tabular}{lc}
\hline \multicolumn{1}{c}{ Genus } & Jumlah \\
\hline Pseudomonas & $72 \times 10^{2} \mathrm{cfu} / \mathrm{ml}$ \\
Aeromonas & $18 \times 10^{2} \mathrm{cfu} / \mathrm{ml}$ \\
\hline
\end{tabular}

\subsection{Isolasi Bakteri Proteolitik}

Dari hasil isolasi diperoleh total bakteri proteolitik sebanyak $23,7 \times 10^{5} \mathrm{cfu} / \mathrm{ml}$. Dari total tersebut, sebanyak 28 isolat bakteri proteolitik berhasil diisolasi dari sampel limbah cair tahu dengan empat kategori indeks proteolitik yaitu $++++=I P \geq 3 ;+++=2 \geq I P \geq 3 ;++=1 ; \geq I P \geq 2$; $+=$ IP $\leq 1$. (Tabel 4). Isolat tersebut kemudian diberi kode BLT. Zona bening bakteri disebabkan adanya aktivitas enzim proteolitik ekstraseluler yang dihasilkan bakteri dalam menghidrolisis kasein yang berada didalam susu skim pada media.

Aktivitas protease dari bakteri proteolitik dilihat dari pembentukan zona bening pada medium padat. Zona bening tersebut merupakan indikator bahwa isolat bakteri mampu memanfaatkan protein pada media sebagai sumber nutrisinya ${ }^{(14)}$. Keberadaan bakteri proteolitik yang mampu menggunakan protein pada media dapat dijadikan sebagai agen untuk mendegradasi protein pada limbah cair tahu. Penggunaan bakteri proteolitik sebagai agen bioremediasi limbah protein telah banyak dilakukan diantaranya limbah surimi dan rajungan ${ }^{(15)}$, limbah bulu ${ }^{(16)}$; limbah babi ${ }^{(5)}$. Penggunaan bakteri proteolitik dalam mengkonversi limbah babi dapat dijadikan sebagai pupuk hayati untuk menghambat penyakit tanaman.

Tabel 4. Hasil Isolasi Bakteri Proteolitik pada Media NA+ Skim Milk 1\%

\begin{tabular}{|c|c|c|c|}
\hline Kode Isolat & Indeks Proteolitik & Kode Isolat & Indeks Proteolitik \\
\hline BLT-01 & +++ & BLT-15 & +++ \\
\hline BLT-02 & ++ & BLT-16 & ++++ \\
\hline BLT-03 & ++ & BLT-17 & ++ \\
\hline BLT-04 & +++ & BLT-18 & ++ \\
\hline BLT-05 & + & BLT-19 & ++ \\
\hline BLT-06 & +++ & BLT-20 & ++ \\
\hline BLT-07 & ++ & BLT-21 & ++++ \\
\hline BLT-08 & + & BLT-22 & + \\
\hline BLT-09 & ++ & BLT-23 & + \\
\hline BLT-10 & ++ & BLT-24 & +++ \\
\hline BLT-11 & + & BLT-25 & +++ \\
\hline BLT-12 & ++++ & BLT-26 & + \\
\hline BLT-13 & ++ & BLT-27 & + \\
\hline BLT-14 & + & BLT-28 & + \\
\hline $\begin{array}{l}\text { Keterangan: } \\
++++=\mathrm{IP} \geq 3 \\
+++\quad=2 \geq \mathrm{IP} \geq 3 \\
++\quad=1 \geq \mathrm{IP} \geq 2 \\
+\quad=\mathrm{IP} \leq 1\end{array}$ & & & \\
\hline
\end{tabular}

\subsection{Kemampuan Bakteri Proteolitik dalam Melarutkan Fosfat}

Dari 28 isolat bakteri proteolitik, selain memiliki kemampuan proteolitik, ke 17 isolat bakteri juga memiliki kemampuan melarutkan fosfat pada media pikovskaya (Tabel 5). Kemampuan bakteri indigenous limbah cair tahu dalam melarutkan fosfat mengindikasikan adanya fosfat yang tinggi dalam limbah sehingga dapat dijadikan sebagai agen pengurai kandungan fosfat didalam limbah cair tahu yang dibuang ke lingkungan. Kondisi lingkungan yang tinggi fosfat mengindikasikan adanya zat pencemar ${ }^{(9)}$.

Selain itu, kemampuan bakteri dalam melarutkan fosfat juga mengindikasikan bahwa bakteri indigenous yang ada di limbah cair tahu dapat digunakan sebagai agen untuk melarutkan fosfat didalam limbah cair tahu. Kemampuan bakteri melarutkan fosfat mampu dijadikan sebagai biofertilizer dan meningkatkan kesuburan tanah. Pada dasarnya komposisi limbah cair tahu sudah memenuhi persyaratan nutrisi yang dibutuhkan oleh bakteri pelarut fosfat untuk tumbuh dan melakukan metabolisme ${ }^{(17)}$ sehingga mampu merombak kandungan fosfat yang komponen limbah tersebut menjadi sesuatu yang lebih berguna. Keberadaan BPF juga mampu meningkatkan ketersedian $\mathrm{P}$ didalam tanah jika digunakan sebagai pupuk hayati ${ }^{(18)}$. 
Tabel 5. Hasil Uji Potensi Pelarut Fosfat Isolat Bakteri pada Media Pikovskaya

\begin{tabular}{cccc}
\hline Kode Isolat & Uji Pelarut Fosfat & Kode Isolat & Uji Pelarut Fosfat \\
\hline BLT-01 & + & BLT-15 & - \\
BLT-02 & + & BLT-16 & + \\
BLT-03 & + & BLT-17 & - \\
BLT-04 & + & BLT-18 & - \\
BLT-05 & - & BLT-19 & + \\
BLT-06 & - & BLT-20 & + \\
BLT-07 & + & BLT-21 & + \\
BLT-08 & - & BLT-22 & + \\
BLT-09 & + & BLT-23 & + \\
BLT-10 & + & BLT-24 & - \\
BLT-11 & + & BLT-25 & + \\
BLT-12 & - & BLT-26 & - \\
BLT-13 & + & BLT-27 & - \\
BLT-14 & + & BLT-28 & - \\
Keterangan : & & & \\
$+=$ Mampu melarutkan P pada media & & \\
$-=$ Tidak mampu melarutkan P pada media &
\end{tabular}

\section{KESIMPULAN}

Dari hasil penelitian yang telah dilakukan diperoleh bahwa produksi limbah cair tahu mencapai 4000 liter/hari. Nilai BOD, COD, total protein dan $\mathrm{pH}$ secara berturut-turut sebesar $3210 \mathrm{mg} / \mathrm{L}, 7102 \mathrm{mg} / \mathrm{L}, 20.74 \%$ dan 5. Total bakteri indigenous dari genus Pseudomonas berjumlah $72 \times 10^{2} \mathrm{cfu} / \mathrm{ml}$, genus Aeromonas berjumlah $18 \times 10^{2} \mathrm{cfu} / \mathrm{ml}$ dan bakteri proteolitik berjumlah $23.7 \times 10^{5}$ $\mathrm{cfu} / \mathrm{ml}$. Jumlah isolat proteolitik yang diperoleh sebanyak 28 isolat dengan kemampuan proteolitik yang cukup beragam. Sebanyak 17 isolat dari 28 isolat tersebut memiliki kemampuan melarutkan fosfat pada media pikovskaya. Hal ini menunjukkan bahwa Jumlah produksi yang tinggi, karakteristik kimia dan keberadaan bakteri indigenous Pseudomonas, Aeromonas, bakteri proteolitik serta bakteri pelarut fosfat pada limbah cair tahu memiliki potensi untuk dikembangkan sebagai salah satu alternatif biokonversi limbah yang dapat berguna untuk memperkaya unsur hara tanah seperti nitrogen dan fosfor sehingga meningkatkan kesuburan tanah.

\section{PERSANTUNAN}

Penulis menyampaikan terima kasih kepada Kemenristekdikti atas dukungan pembiayaan penelitian ini melalui Program Hibah Penelitian Dosen Pemula kepada Muhammad Asril dengan Nomor SPPK: 007/SP2H/LT/DRPM/2018 dan kepada Institut Teknologi Sumatera.

\section{DAFTAR PUSTAKA}

1. Faisal, M., Gani, A., Maulana, F., \& Daimon, H. (2016). Treatment and utilization of industrial tofu waste in Indonesia. Asian Journal of Chemistry, 28(3), 501-507.

2. Sintawardani, N. (2011). Socio-economic problem on reducing the waste water pollution from tofu processing in the Cibuntu area, Indonesia. Research Center for physics Indonesian Insitute of Science.

3. Faisal, M., Maulana, F., Alam, P. N., \& Daimon, H. (2014). Wastewater characteristics from tofu processing facilities in Banda Aceh. The proceedings of The $4^{\text {th }}$ Annual International Conference Syiah Kuala University (AIC Unsyiah). Oktober 22-24. Banda Aceh, Indonesia, 1821.

4. Belen, F., Sanchez, J., Hernandez, E., Auleda, J. M., \& Raventos, M. (2012). One option for the management of wastewater from tofu production: Freeze concentration in a falling-film system. Journal of Food Engineering, 110 (3), 364-373.

5. Dutta, S., Park, Y. S., \& Park, K. (2016). Proteolytic activity of thermophilic Bacillus licheniformis strain SF5-1 for the efficient bioconversion of pork waste to amino acid fertilizer. International Biodeterioration \& Biodegradation, 111, 31-36.

6. Durham, D. R., Stewart, D. B., \& Stellwag, E. J. (1987). Novel alkaline and heat stable serine proteases from alkaliphilic Bacillus 
sp. strain GX6638. Journal of Bacteriology, 169(6), 2762-2768.

7. Aliyenah, Napoleon, A., \& Yudono, B. (2015). Pemanfaatan limbah cair industri tahu sebagai pupuk cair organik terhadap pertumbuhan dan produksi tanaman kangkung darat (Ipomea reptans Poir). Jurnal Penelitian Sains, 17(3), 102-110.

8. Faisal, M., Machdar, I., Mulana, F., \& Daimon, H. (2014). Potential renewable energy from tofu processing waste in Banda Aceh City, Indonesia. Asian Journal of Chemistry, 26(10), 6610-6604.

9. Makmur, M., Kusnoputranto, H., Moersidik, S.S., \& Wisnubroto, D.S. (2012). Pengaruh Limbah Organik dan Rasio N/P terhadap Kelimpahan Fitoplankton di Kawasan Budidaya Kerang Hijau Cilincing. Jurnal Teknologi Pengelolaan Limbah, 15(2), 5164.

10. Wijana, I. M. S., Dewi, I. G. A., \& As-Syakur A. R. (2012). Studi dan Pemantauan Kualitas Air di Daerah Aliran Sungai (DAS) Badung. Ecotrophic, 7(1), 54-58.

11.Suryanti, V., Handayani, D. S., Marliyana, S. D., \& Suratmi, S. (2017). Physicochemical properties of biosurfactant produced by Pseudomonas fluorescens grown on whey tofu. IOP Conference Series: Materials Science and Engineering, 176, 1-6

12. Couillerot, O., Combaret, C. P., Mellado, J. C., \& Loccoz, Y. M. (2009). Pseudomonas fluorescens and closely-related fluorescent pseudomonads as biocontrol agents of soilborne phytopathogens. Lett. Appl. Microbiol, 48, 505-512.
13. Ariawan, I. W. G., Suprapta, D. N. \& Suniti, N.W. (2015). Pemanfaatan Aeromonas hydrophila untuk mengendalikan penyakit layu Fusarium pada beberapa varietas sorgum manis (Sorghum bicolor (L.) Moench). Agroteknologi Tropika, 4(2), 8192

14.Badriyah, B. I., \& Ardyati, T. (2013). Deteksi Aktivitas proteolitik isolat bakteri asal ampas tahu pada substrat bekatul. Jurnal Biotropika, 1(3),109-113..

15. Oktavia, D. A., Mangunwidjaja, D., Wibowo, S., Sunarti, T. C., \& Rahayuningsih, M. (2012). Pengolahan limbah cair perikanan menggunakan konsosrsium mikroba indigenous proteolitik dan lipolitik. Agrointek, 6(2), 65-71.

16. de Oliveira, C. T., Pellenz, L., Pereira, J. Q., Brandelli, A., \& Daroit, D. J. (2016). Screening of Bacteria for Protease Production and Feather Degradation. Water \& Biomass Valorization, 7(3), 447453.

17.Alawiah, S. D., Darmayasa, I. B. G., \& Sundra, I. K. (2015). Isolasi dan optimalisasi pertumbuhan bakteri pelarut fosfat (BPF) pada limbah cair tahu cair dengan menggunkaan konsentrasi karbon C yang berbeda. Jurnal Simbiosis, 3(1), 326-329.

18. Hidayani, Sufardi, \& Hakim, L. (2015). Limbah tahu untuk memperbaiki sifat kimia dan biologi tanah serta hasil tanaman jagung manis (Zea mays var. saccharata Sturt L.). Jurnal Manajemen Sumberdaya Lahan, 4(1), 572-578. 